\title{
Short-term Effects of Cover Crop Management on Soil Organic Matter and Soil Alteration Index Three in the Western Cape Province
}

\author{
Adewole T. Adetunji, Bongani Ncube, Andre H. Meyer, Reckson Mulidzi, Joseph Kioko and Francis B. \\ Lewu
}

\begin{abstract}
This study assessed the effect of four living cover crops (CC) and residues, two termination stages and two termination methods on soil organic matter (SOM) and alteration index three (AI3) at two experimental sites, in the Western Cape, South Africa, over one year. Species tested as CCs were, vetch, pea, oats, rye and control (no CC). Soil was sampled at kill and one year later. Living CCs and residues were slow to affect SOM and AI3. Oats residue is the most promising of the $\mathrm{CC}$ species with regards to SOM accrual. Termination of CCs at the flowering stage favoured SOM and AI3 than the vegetative stage at one year. While no responses were detected at Nietvoorbij site, termination of CCs by slashing improved SOM compared to spraying, at Bien Donne site. The response of AI3 to termination methods was only observed at Nietvoorbij site with slash having a positive effect compared to spray treatment.
\end{abstract}

Keywords - Alteration index three, cover crop, organic matter, soil enzyme, termination.

\section{INTRODUCTION}

There is a growing concern about the degradation of agricultural soils due to conventional farming practices and misuse of soil resources. This has led to a significant decline in agricultural production, biodiversity, and other ecosystem services [1]. Several methods have been used for decades to improve soil quality including cover cropping. Cover cropping can serve as a sustainable approach to combat soil degradation, provide organic matter and improve microbial processes and fertility in agricultural soils [2]. However, proper management is required to realize many of the benefits associated with cover crops (CC).

Studies have shown that changes in the whole population or certain species of soil microbial communities can be used as

Manuscript received August 18, 2020. This work was supported by the Cape Peninsula University of Technology (CPUT) University Research Fund (URF RE86).

A. T. Adetunji and F. B. Lewu are with Department of Agriculture, Cape Peninsula University of Technology, Wellington 7655, Western Cape, South Africa

B. Ncube is with Centre for Water and Sanitation Research, Department of Civil Engineering, Cape Peninsula University of Technology, Bellville, 7535, Western Cape, South Africa.

A. H. Meyer and R. Mulidzi are with Agricultural Research Council, Infruitec-Nietvoorbij, Private Bag X5026, Stellenbosch 7599, South Africa.

J. Kioko is with Faculty of Applied Sciences, Cape Peninsula University of Technology, Cape Town, 8000, South Africa. reliable signals of changes in soil quality [3]. Soil biological quality measurements are therefore becoming increasingly important in evaluating the impacts of soil management practices and the sustainability of land-use in agricultural soils $[4,5]$. There is a growing scientific interest in the use of enzymatic activity as an agricultural soil quality indicator because enzymatic relationships with soil biology are integrative, very sensitive, operationally practical, easy to quantify and relate to soil tillage and structure [6]. Soil enzymes catalyse several biochemical reactions which result in the transformation of organic matter, and the release of inorganic nutrients for plant growth and nutrient cycling [6, 7]. Therefore, the analysis of soil enzyme activity can provide an early and dynamic indication of soil quality changes in agriculture [8]. A number of studies have indicated higher $\beta$-glucosidase, urease and phosphatase activities in $\mathrm{CC}$ and organic residue amended soils compared to fallow soils $[9,10]$. Nonetheless, there is limited research on the effect of $\mathrm{CC}$ species, termination stage and termination method on the activities of these soil enzymes in South African cropping systems [2, 10], although CCs are an important component of agricultural systems, especially in fruit production.

Soil alteration index three (AI3) was first used in a study to examine the effect of different management and treatment regimes on soil enzyme activities [11]. The soil AI3 measures the balance between three soil enzymes ( $\beta$-glucosidase, urease and phosphatase) and smaller values of AI3 correlates with greater soil quality [11]. Other studies have used AI3 to monitor soil quality status in the temperate grasslands of Galicia, North West Spain [12], conventional and organic treated apple orchards of Western Cape, South Africa [13] and compost amended soils in France [14]. Recently the response of soil AI3 and soil organic matter (SOM) to CC species, termination stage and termination method was examined in a greenhouse pot experiment in Western Cape, South Africa [15]. However, it is important to further evaluate the effect of these CC management practices at the field level. This will aid proper selection and development of management approaches that will result in the restoration of healthy microbial communities, fertility and sustainability of agricultural soils. Therefore, the objectives of this study were to determine the effect of living CCs and residues, termination stage and termination method on SOM and AI3 at two field sites in the Western Cape. 


\section{MATERIALS AND METHODS}

\section{A. Experimental description}

The study was conducted from 2017 to 2018 at two fallow sites, $42 \mathrm{~km}$ apart; at the Agricultural Research Council (ARC) Nietvoorbij Research Farm (33 55'10''S, 18 51'57' E) and ARC Bien Donne Research Farm (3350'30'’S, 1858'59' 'E), in the Western Cape Province, South Africa. The sites are under Mediterranean climate, with a mean annual temperature of about $18^{\circ} \mathrm{C}$, a January mean of about $24^{\circ} \mathrm{C}$ and a July mean of about $13^{\circ} \mathrm{C}$. A randomized block design was used and each treatment was replicated three times, at both sites. Four experiments were set up which included two growth termination stages (vegetative and flowering) and two termination methods (slash and spray). Each experiment consisted of five CCs namely; oats (Avena sativa L.), rye (Secale cereal L.), pea (Pisum sativum), vetch (Vicia dasycarpa Ten.) and a control (no $\mathrm{CC})$. The soil $(0-15 \mathrm{~cm}$ depth) at the Nietvoorbij site was a sandy clay loam with $53 \%$ sand, $16 \%$ silt and $31 \%$ clay, a $\mathrm{pH}$ (KCl) of 5.5, 1.29\% C, 2.2\% SOM, $12 \mathrm{mg} \mathrm{kg}^{-1} \mathrm{P}$ (Bray II), 25 $\mathrm{mg} \mathrm{kg}^{-1} \mathrm{~K}, 2.09 \mathrm{mg} \mathrm{kg}^{-1} \mathrm{NO}_{3}-\mathrm{N}$ and $9.03 \mathrm{mg} \mathrm{kg}^{-1} \mathrm{NH}_{4}-\mathrm{N}$. The soil at the Bien Donne site was a sandy loam with $75 \%$ sand, $6 \%$ silt and 19\% clay, a $\mathrm{pH}(\mathrm{KCl})$ of 5.8, 1.04\% C, 1.78\% SOM, 50 $\mathrm{mg} \mathrm{kg}^{-1} \mathrm{P}$ (Bray II), $20 \mathrm{mg} \mathrm{kg}^{-1} \mathrm{~K}, 4.63 \mathrm{mg} \mathrm{kg}^{-1} \mathrm{NO}_{3}-\mathrm{N}$ and 5.15 mg kg-1 $\mathrm{NH}_{4}-\mathrm{N}$. Row spacing was $2 \mathrm{~m}$ at both sites while plot size for each replicate was $2 \mathrm{~m}$ by $2 \mathrm{~m}$ at Nietvoorbij and $3 \mathrm{~m}$ by $2 \mathrm{~m}$ at Bien Donne.

Cover crops were broadcast by hand and covered with soil (about $3 \mathrm{~cm}$ ) with a shallow rake, on 9 June 2017 and 11 July 2017 at Bien Donne and Nietvoorbij, respectively. At both sites, seeding rates were as follows: pea, $80 \mathrm{~kg} \mathrm{ha}^{-1}$; vetch, $50 \mathrm{~kg} \mathrm{ha}^{-1}$; oats, $100 \mathrm{~kg} \mathrm{ha}^{-1}$; rye, $100 \mathrm{~kg} \mathrm{ha}^{-1}$ [16]. At Nietvoorbij, fertilizer was applied at $7 \mathrm{~kg} \mathrm{~N} \mathrm{ha}^{-1}$ and $10 \mathrm{~kg} \mathrm{P} \mathrm{ha}^{-1}$ on each plot, at planting. At Bien Donne, oats and rye plots received 7 $\mathrm{kg} \mathrm{N} \mathrm{ha}^{-1}$ and $5 \mathrm{~kg} \mathrm{P} \mathrm{ha}^{-1}$ while pea and vetch plots received only $5 \mathrm{~kg} \mathrm{P} \mathrm{ha}^{-1}$ at 3 - 4 leaf stage. Neither CC nor fertilizer was present in the control plots. Vetch and pea were inoculated with Rhizobium leguminosarium biovar viciae, before planting. Weeds were not controlled and plots were mainly rainfed. Cover crops were terminated at vegetative growth stage (Nietvoorbij: September 27 and October 4, 2017 and Bien Donne: September 8 and 14, 2017) and flowering stage (Nietvoorbij: October 18 and 20, 2017 and Bien Donne: September 29 and October 5, 2017) by clipping at the soil level and spraying glyphosate (N-phosphonomethyl glycine) at the rate of $5 \mathrm{~L} \mathrm{ha}^{-1}$. The $\mathrm{CC}$ residues were left on the soil surface to decompose.

\section{B. Soil sampling and analysis}

Soil samples were randomly collected from 3 points per treatment plot ( 0 - $15 \mathrm{~cm}$ depths $)$ just before $\mathrm{CC}$ termination (hereafter referred to as kill) and at one year after. The composite soil samples were passed through a $2 \mathrm{~mm}$ mesh. The SOM content of the samples was determined by combustion analysis [17]. The activities of $\beta$-glucosidase, phosphatase and urease known to play a critical role in carbon, phosphorus and nitrogen cycle, respectively, were determined from each sample using colorimetric methods [18-20]. The activities of $\beta$-glucosidase and phosphatase were expressed as $\mu \mathrm{g}$ $p$-nitrophenol $\mathrm{g}^{-1}$ soil $\mathrm{h}^{-1}$ while urease activity was expressed as $\mu \mathrm{g}$ ammonium $\mathrm{g}^{-1}$ soil $2 \mathrm{~h}^{-1}$. The AI3 was calculated using the $\mathrm{AI} 3$ equation.

Alteration index three equation

$\mathrm{AI} 3=7.87 \beta$-glucosidase -8.22 phosphatase -0.49 urease (Equation 1)

\section{Statistical analysis}

The trials were conducted at two sites. Levene's test for homogeneity of experimental variances was verified for comparable variances [21]. The data were then subjected to a combined analysis of variance (ANOVA) using General Linear Models Procedure (PROC GLM) of Statistical Analysis Software (SAS) (Version 9.4; SAS Institute Inc, Cary, USA). Observations over sampling time (kill and one year) were combined in a split-plot analysis of variance with sampling time as a sub-plot factor [22] for soil variables. The Shapiro-Wilk test was performed on the standardized residuals from the model to verify normality [23]. Fisher's least significant difference was calculated at the 5\% level to compare treatment means [24]. A probability level of $5 \%$ was considered significant for all significance tests.

\section{RESULTS AND DISCUSSION}

\section{A. Effect of cover crop species and sampling time on SOM and $A I 3$}

At kill, living CCs had no significant effect on SOM, at the Nietvoorbij site. Compared to oats, vetch and control plots, SOM concentration was significantly and marginally higher in living pea $(1.72 \%)$ and rye $(1.68 \%)$ plots, respectively, at the Bien Donne site (Table I). In this study, the significant effect of living CCs on SOM concentrations was observed at Bien Donne against the Nietvoorbij site. The observed non-responsiveness of SOM to living CC at Nietvoorbij site is consistent with the previous greenhouse study that was done using similar soil [15]. The initial higher $\mathrm{C}$ content detected in Nietvoorbij soil than Bien Donne soil might have contributed to SOM being undetectable in the short-term [25]. The significantly and marginally higher SOM in living pea and rye plots, respectively, compared to the control at the Bien Donne site, is an indication that these CCs can improve SOM through their root exudates and root turnover [26] in the short-term. At one year, oats residue significantly increased SOM at both sites, compared to other treatments (Table I). The marked increase in SOM under oats residue treatment compared to the control at both sites is in agreement with previous studies in the Western Cape cropping system [27] including the recent greenhouse study with similar soil [15]. However, several studies have shown that an increase in SOM concentration due to $\mathrm{CC}$ amendment is not usually detected early, but rather in the long term [28].

At kill, living CCs had no significant effect on AI3, at both sites (Table I). This is in contrast with the results from the preceding greenhouse pot experiment with Nietvoorbij soil type, which showed significantly lower AI3 values under oats, rye, pea and vetch soils compared to the control [15]. However, the AI3 value was significantly lower in living pea treatment 
(-44.27) than oats $(-33.50)$ and rye (-30.08), and marginally lower in living pea treatment $(-44.27)$ than the control $(-39.06)$, at Nietvoorbij site. In living rye $(-16.66)$ and vetch $(-16.63)$ treatments had marginally lower AI3 values than the pea (-14.83), oats (-14.70) and control (-14.85), at the Bien Donne site (Table I). The conflicting findings between the field and greenhouse pot experiment may be due to the larger soil surface area in the field which perhaps caused a slow rate of alteration in enzyme activities in response to the presence of living CCs. At one year, there were no significant differences in AI3 values under plots with $\mathrm{CC}$ residues and the control, at both sites (Table I), which is consistent with the previous greenhouse pot experiment [15]. Apart from this study, there is only one report [15] on the effect of CC species on AI3. Therefore, more short and long term studies are needed to confirm the previous and current results as well as evaluate the suitability/sensitivity of AI3 for measuring soil quality changes due to CC management practices.

TABLE I: COVER CROP SPECIES AND SAMPLING TIME EFFECTS ON SOIL ORGANIC MATTER (SOM) AND SOIL ALTERATION INDEX THREE (AI3) AT NIETVOORBIJ AND BIEN DONNE STUDY SITES

\begin{tabular}{|c|c|c|c|c|c|}
\hline \multirow[t]{2}{*}{ ST } & \multirow{2}{*}{$\mathrm{CC}$} & \multicolumn{2}{|l|}{ Nietvoorbij } & \multicolumn{2}{|c|}{ Bien Donne } \\
\hline & & SOM $(\%)$ & $\mathrm{AI} 3$ & SOM (\%) & $\mathrm{AI} 3$ \\
\hline \multirow[t]{5}{*}{ Kill } & Oats & $2.10^{\mathrm{ab}}$ & $-33.50^{\mathrm{a}}$ & $1.63^{\mathrm{bc}}$ & $-14.70^{\mathrm{a}}$ \\
\hline & Pea & $2.01^{\mathrm{ab}}$ & $-44.27^{\mathrm{b}}$ & $1.72^{\mathrm{a}}$ & $-14.83^{\mathrm{ab}}$ \\
\hline & Rye & $1.96^{\mathrm{ab}} \mathrm{c}$ & $-30.08^{\mathrm{a}}$ & $1.68^{\mathrm{ab}}$ & $-16.66^{\mathrm{abc}}$ \\
\hline & Vetch & $2.16^{\mathrm{a}}$ & $\begin{array}{l}-34.29^{\mathrm{a}} \\
\mathrm{b}\end{array}$ & $1.56^{\mathrm{bc}}$ & $-16.63^{\mathrm{abc}}$ \\
\hline & Control & $2.01^{\mathrm{ab}}$ & $\begin{array}{l}-39.06^{\mathrm{a}} \\
\mathrm{b}\end{array}$ & $1.54^{\mathrm{bc}}$ & $-14.85^{\mathrm{ab}}$ \\
\hline \multirow[t]{5}{*}{ One year } & Oats & $2.19^{\mathrm{a}}$ & $\begin{array}{l}-38.08^{\mathrm{a}} \\
\mathrm{b}\end{array}$ & $1.70^{\mathrm{a}}$ & $-18.34^{\text {cd }}$ \\
\hline & Pea & $2.04^{\mathrm{ab}}$ & $-33.63^{\mathrm{a}}$ & $1.58^{\mathrm{bc}}$ & $-19.94^{\mathrm{d}}$ \\
\hline & Rye & $1.97^{\mathrm{ab}}$ & $\begin{array}{l}-39.25^{\mathrm{a}} \\
\mathrm{b}\end{array}$ & $1.40^{\mathrm{c}}$ & $\begin{array}{l}-17.40^{\mathrm{abc}} \\
\mathrm{d}\end{array}$ \\
\hline & vetch & $1.98^{\mathrm{ab}}$ & $-36.45^{\mathrm{a}}$ & $1.55^{\mathrm{bc}}$ & $-18.78^{\mathrm{cd}}$ \\
\hline & Control & $1.91^{\mathrm{bcd}}$ & $-38.50^{\mathrm{a}}$ & $1.66^{\mathrm{b}}$ & $-17.95^{\mathrm{bcd}}$ \\
\hline
\end{tabular}

ST and CC denotes sampling time and cover crop, respectively. Each value represents the mean $(\mathrm{n}=3)$. Different letters within a column indicate significant differences $(\mathrm{P}<0.05)$ among treatments using Fisher's least significant difference test (LSD)

\section{B. Effect of termination stage on SOM and AI3 at different sampling times}

At kill, SOM was considerably higher at the flowering stage than vegetative, when averaged over all living CC plots, at both sites (Table II). The results indicate that living CCs improve SOM when terminated at the flowering stage compared to the vegetative stage. This is in contrast to the findings from the previous greenhouse pot experiment where Nietvoorbij soil was used. However, some studies have reported that living CCs build-up soil organic carbon through root exudates released via passive and active mechanisms [26]. Thus, in this study, delay in termination of $\mathrm{CCs}$ might have contributed to the accumulation of root exudates which resulted in higher SOM observed at the flowering stage compared to the vegetative stage. At one year, SOM at the flowering stage $(1.85 \%)$ remained significantly higher than vegetative $(1.31 \%)$ at the
Bien Donne site, while no significant differences were observed between termination stages at the Nietvoorbij site (Table II). Notably, just like the results from the Bien Donne site, the preliminary pot experiment with Nietvoorbij soil had higher SOM at the flowering stage than the vegetative stage, at one year [15]. The higher SOM content observed at the flowering stage compared to vegetative is consistent with other studies which showed that delayed termination of CCs correlated with higher biomass, residue cover, SOM and SOC content [29, 30].

At both sampling times, flowering stage had lower AI 3 values compared to the vegetative stage, when averaged over all CCs at Nietvoorbij and Bien Donne sites (Table II). The findings are in contrast with the earlier greenhouse pot experiment which had lower AI3 values at the vegetative stage compared to the flowering stage [15]. However, the current results may be linked to reports which indicated that delay in termination may lead to the accrual of plant root exudates and greater microbial biomass, which favours enzyme activities [31]. Further long-term research is required to show whether or not these observations transcend.

TABLE II: THE AVERAGE EFFECT OF TERMINATION STAGE ON SOIL ORGANIC MATTER (SOM) AND SOIL ALTERATION INDEX THREE (AI3) AT DIFFERENT SAMPLING TIMES (KILL AND ONE YEAR) AT NIETVOORBIJ AND BIEN DONNE STUDY SITES

\begin{tabular}{|c|c|c|c|c|c|}
\hline \multirow[t]{2}{*}{ ST } & \multirow[t]{2}{*}{$\begin{array}{l}\text { Termination } \\
\text { stage }\end{array}$} & \multicolumn{2}{|l|}{ Nietvoorbij } & \multicolumn{2}{|l|}{$\begin{array}{l}\text { Bien } \\
\text { Donne }\end{array}$} \\
\hline & & SOM (\%) & $\mathrm{AI} 3$ & SOM $(\%)$ & $\mathrm{AI} 3$ \\
\hline \multirow[t]{2}{*}{ Kill } & Vegetative & $1.85^{\mathrm{c}}$ & $\begin{array}{l}-31.94 \\
\mathrm{a}\end{array}$ & $1.57^{\mathrm{c}}$ & $-10.77^{\mathrm{a}}$ \\
\hline & Flowering & $2.24^{\mathrm{a}}$ & $\begin{array}{l}-40.54 \\
\text { b }\end{array}$ & $1.69^{\mathrm{b}}$ & $-20.30^{c}$ \\
\hline \multirow[t]{2}{*}{$\begin{array}{l}\text { One } \\
\text { year }\end{array}$} & Vegetative & $2.06^{\mathrm{ab}}$ & $\begin{array}{l}-33.08 \\
\text { a }\end{array}$ & $1.31^{\mathrm{d}}$ & $-18.00^{b}$ \\
\hline & Flowering & $1.98^{\mathrm{b}}$ & $\begin{array}{l}-41.28 \\
\mathrm{~b}\end{array}$ & $1.85^{\mathrm{a}}$ & ${ }_{c}^{-18.96^{b}}$ \\
\hline
\end{tabular}

ST denotes sampling time. Different letters within a column indicate significant differences at $\mathrm{P}<0.05$ according to Fisher's least significant difference test (LSD)

\section{Effect of termination method on SOM and AI3}

At one year, there was no significant difference in SOM between slash and spray plots, when averaged over all CC species, at Nietvoorbij site (Table III). This is in contrast with the previous greenhouse study with similar soil which showed higher SOM in slash plots than spray [15]. However, at the Bien Donne site, SOM was significantly higher under slash plots $(1.70 \%)$ than spray $(1.47 \%)$, at one year (Table III), which is consistent with the previous greenhouse work [15]. The major difference between both termination methods is that slash allows better surface residue cover and contact with the soil and maintains lower soil temperature and moisture which all contribute to higher SOM build-up and microbial activity [32].

At one year, the AI3 value was significantly lower in slash (-40.97) treatments than spray (-33.39) when averaged over all $\mathrm{CC}$ residues, at the Nietvoorbij site (Table III). This is in contrast with the previous greenhouse pot experiment with similar soil [15]. However, termination method had no significant effect on $\mathrm{AI} 3$ values, at the Bien Donne site (Table III). The soil AI3 value was nevertheless slightly lower in slash than spray plots, at Bien Donne. Previous studies have shown 
that the accumulation of herbicides including glyphosate could be toxic to microbes thereby affecting their activities $[2,33]$. The results indicate site effect, since no significant effect was detected at the Bien Donne field, whereas CC termination by slash considerably and positively affected AI3 compared to spraying at Nietvoorbij.

TABLE III: THE AVERAGE EFFECT OF TERMINATION METHOD (SLASH AND SPRAY) ON SOIL ORGANIC MATTER (SOM) AND SOIL ALTERATION INDEX THREE (AI3) AT ONE YEAR AT NIETVOORBIJ AND BIEN DONNE STUDY SITES

\begin{tabular}{lllll}
\hline \multirow{2}{*}{ Termination method } & Nietvoorbij & \multicolumn{3}{c}{ Bien Donne } \\
\cline { 2 - 5 } & SOM $(\%)$ & AI3 $(\%)$ & SOM $(\%)$ & AI3 (\%) \\
\hline Slash & $2.06^{\mathrm{a}}$ & $-40.97^{\mathrm{b}}$ & $1.70^{\mathrm{a}}$ & $-19.07^{\mathrm{a}}$ \\
Spray & $1.98^{\mathrm{a}}$ & $-33.39^{\mathrm{a}}$ & $1.47^{\mathrm{b}}$ & $-17.89^{\mathrm{a}}$ \\
\hline
\end{tabular}

Different letters within a column indicate significant differences $(\mathrm{P}<0.05)$ among treatments using Fisher's least significant difference test (LSD)

\section{CONCLUSION}

In this study, living CCs had no considerable impact on SOM. However, out of the tested CCs, oats residues appeared to increase SOM in the short-term. Living CCs and residues had no significant effect on $\mathrm{AI} 3$, in the short-term. Compared to the vegetative stage, delaying the termination of $\mathrm{CCs}$ until the flowering stage improved SOM and AI3. The impact of termination method on SOM was only observed at the Bien Donne site with the slash treatment being higher than spraying. Also, the response of AI3 to termination methods was only observed at Nietvoorbij site with slash having significantly lower values (more favourable) than spray treatment. Site effect was noticeable in this study, especially with regards to termination methods. Findings from this field study indicate that longer periods may be needed to examine the response of SOM and $\mathrm{AI} 3$ to $\mathrm{CCs}$ in this Mediterranean environment.

\section{ACKNOWLEDGMENT}

We thank Barenbrug South Africa for supplying us with cover crop seeds. We also thank Ms Isabella Van Huyssteen and Mr Ncedo Ndololwana (Soil Science Department, ARC Infruitec/Nietvoorbij) for their technical support.

\section{REFERENCES}

[1] Delgado, J. A. and C. J. Gantzer, The 4Rs for cover crops and other advances in cover crop management for environmental quality. Journal of Soil and Water Conservation, 2015. 70(6): pp. 142A-145A. https://doi.org/10.2489/jswc.70.6.142A

[2] Adetunji, A. T., B. Ncube, R. Mulidzi, and F. B. Lewu, Management impact and benefit of cover crops on soil quality: A review. Soil and Tillage Research, 2020. 204: pp. 104717. https://doi.org/10.1016/j.still.2020.104717

[3] Karaca, A., S. C. Cetin, O. C. Turgay, and R. Kizilkaya, Soil enzymes as indication of soil quality, in Soil enzymology. 2010, Springer: Berlin, Heidelberg. pp. 119-148. https://doi.org/10.1007/978-3-642-14225-3_7

[4]Shukla, M., R. Lal, and M. Ebinger, Determining soil quality indicators by factor analysis. Soil and Tillage Research, 2006. 87(2): pp. 194-204. https://doi.org/10.1016/j.still.2005.03.011

[5]Mganga, K. Z., B. S. Razavi, and Y. Kuzyakov, Land use affects soil biochemical properties in Mt. Kilimanjaro region. Catena, 2016. 141: pp. 22-29.

https://doi.org/10.1016/j.catena.2016.02.013
[6] Adetunji, A. T., B. Ncube, R. Mulidzi, and F. B. Lewu, Potential Use of Soil Enzymes as Soil Quality Indicators in Agriculture. Frontiers in Soil and Environmental Microbiology, 2020: pp. 57-64. https://doi.org/10.1201/9780429485794-6

[7]Baležentienè, L., Hydrolases related to $\mathrm{C}$ and $\mathrm{N}$ cycles and soil fertility amendment: Responses to different management styles of agro-ecosystems. Polish Journal of Environmental Studies, 2012. 21(5): pp. 1153-1159.

[8]Adetunji, A. T., F. B. Lewu, R. Mulidzi, and B. Ncube, The biological activities of $\beta$-glucosidase, phosphatase and urease as soil quality indicators: a review. Journal of Soil Science and Plant Nutrition, 2017. 17(3): pp. 794-807. https://doi.org/10.4067/S0718-95162017000300018

[9]Mukumbareza, C., P. Muchaonyerwa, and C. Chiduza, Effects of oats and grazing vetch cover crops and fertilisation on microbial biomass and activity after five years of rotation with maize. South African Journal of Plant and Soil, 2015. 32(4): pp. 189-197. https://doi.org/10.1080/02571862.2015.1025446

[10] Adetunji, A. T., B. Ncube, A. H. Meyer, R. Mulidzi, and F. B. Lewu, Soil $\beta$-glucosidase activity, organic carbon and nutrients in plant tissue in response to cover crop species and management practices. South African Journal of Plant and Soil, 2020: pp. 1-9. https://doi.org/10.1080/02571862.2020.1718786

[11] Puglisi, E., A. Del Re, M. Rao, and L. Gianfreda, Development and validation of numerical indexes integrating enzyme activities of soils. Soil Biology and Biochemistry, 2006. 38(7): pp. 1673-1681. https://doi.org/10.1016/j.soilbio.2005.11.021

[12] Paz-Ferreiro, J., C. Trasar-Cepeda, M. Leirós, S. Seoane, and F. Gil-Sotres, Biochemical properties in managed grassland soils in a temperate humid zone: modifications of soil quality as a consequence of intensive grassland use. Biology and fertility of soils, 2009. 45(7): pp. 711-722. https://doi.org/10.1007/s00374-009-0382-y

[13] Meyer, A. H., J. Wooldridge, and J. F. Dames, Relationship between soil alteration index three (AI3), soil organic matter and tree performance in a 'Cripps Pink'/M7 apple orchard. South African Journal of Plant and Soil, 2014. 31(3): pp. 173-175. https://doi.org/10.1080/02571862.2014.944229

[14] Riah, W., N. Cheviron, J. Trap, S. Criquet, S. Houot, A. Bispo, C. Grand, G. Pérès, K. Laval, and I. Trinsoutrot-Gattin. Effect or organic amendments on soil enzymatic activities. Results of the" Bioindicators" French program. in "RAMIRAN 2013. 15th International Conference, Versailles, France, 3-5 June. 2013. Proceedings". 2013. Institut National de la Recherche Agronomique (INRA).

[15] Adetunji, A. T., B. Ncube, A. H. Meyer, R. Mulidzi, and F. B. Lewu. Soil Alteration Index Three and Soil Organic Matter in Response to Cover Crop Species and Management Practices. in "16th SOUTH AFRICA International Conference on Agricultural, Chemical, Biological \& Environmental Sciences". 2019. Johannesburg.

[16] Fourie, J., P. Louw, and G. Agenbag, Effect of seeding date on the performance of grasses and broadleaf species evaluated for cover crop management in two wine grape regions of South Africa. South African Journal of Plant and Soil, 2001. 18(3): pp. 118-127. https://doi.org/10.1080/02571862.2001.10634415

[17] Wooldridge, J., J. Fourie, and M. E. Joubert, Effects of soil surface management practices on soil and tree parameters in a 'Cripps Pink'/M7 apple orchard 1. Mineral nutrition. South African Journal of Plant and Soil, 2013. 30(3): pp. 163-170. https://doi.org/10.1080/02571862.2013.848948

[18] Tabatabai, M. and J. Bremner, Use of p-nitrophenyl phosphate for assay of soil phosphatase activity. Soil biology and biochemistry, 1969. 1(4): pp. 301-307. https://doi.org/10.1016/0038-0717(69)90012-1

[19] Eivazi, F. and M. Tabatabai, Glucosidases and galactosidases in soils. Soil Biology and Biochemistry, 1988. 20(5): pp. 601-606. https://doi.org/10.1016/0038-0717(88)90141-1

[20] Kandeler, E. and H. Gerber, Short-term assay of soil urease activity using colorimetric determination of ammonium. Biology and Fertility of Soils, 1988. 6(1): pp. 68-72. https://doi.org/10.1007/BF00257924 
[21] Levene, H., Robust tests for equality of variances, p 278-292. Contributions to probability and statistics: essays in honor of Harold Hotelling. Stanford University Press, Palo Alto, CA, 1960.

[22] Little, T. M. and F. Hills, Statistical Methods in Agricultural Research UCD Book Store. 1972: University of California Davis.

[23] Shapiro, S. S. and M. B. Wilk, An analysis of variance test for normality (complete samples). Biometrika, 1965: pp. 591-611. https://doi.org/10.1093/biomet/52.3-4.591

[24] Ott, R. L. and M. T. Longnecker, An introduction to statistical methods and data analysis. 2015: Nelson Education.

[25] Lagomarsino, A., M. Moscatelli, A. Di Tizio, R. Mancinelli, S. Grego, and S. Marinari, Soil biochemical indicators as a tool to assess the short-term impact of agricultural management on changes in organic $\mathrm{C}$ in a Mediterranean environment. Ecological Indicators, 2009. 9(3): pp. 518-527. https://doi.org/10.1016/j.ecolind.2008.07.003

[26] Dignac, M.-F., D. Derrien, P. Barré, S. Barot, L. Cécillon, C. Chenu, T. Chevallier, G. T. Freschet, P. Garnier, and B. Guenet, Increasing soil carbon storage: mechanisms, effects of agricultural practices and proxies. A review. Agronomy for Sustainable Development, 2017. 37(2): pp. 14. https://doi.org/10.1007/s13593-017-0421-2

[27] Fourie, J., G. Agenbag, and P. Louw, Cover crop management in a Chardonnay/99 Richter vineyard in the coastal region, South Africa. 3. Effect of different cover crops and cover crop management practices on organic matter and macro-nutrient content of a medium-textured soil. South African Journal for Enology and Viticulture, 2007. 28(1): pp. 61. https://doi.org/10.21548/28-1-1461

[28] Acuña, J. and M. B. Villamil, Short-term effects of cover crops and compaction on soil properties and soybean production in Illinois. Agronomy Journal, 2014. 106(3): pp. 860-870. https://doi.org/10.2134/agronj13.0370

[29] Hirpa, T., Effect of stage at termination of legume green manures on soil organic carbon, yield and economic performance of subsequent maize crop. International Journal of Current Research and Academic Review, 2013. 1: pp. 84-101.

[30] Ruis, S., H. Blanco-Canqui, P. J. Jasa, R. Ferguson, and G. Slater, Can cover crop use allow increased levels of corn residue removal for biofuel in irrigated and rainfed systems? BioEnergy Research, 2017. 10(4): pp. 992-1004. https://doi.org/10.1007/s12155-017-9858-z

[31] Boyrahmadi, M. and F. Raiesi, Plant roots and species moderate the salinity effect on microbial respiration, biomass, and enzyme activities in a sandy clay soil. Biology and Fertility of Soils, 2018. 54(4): pp. 509-521. https://doi.org/10.1007/s00374-018-1277-6

[32] Liang, S., J. Grossman, and W. Shi, Soil microbial responses to winter legume cover crop management during organic transition. European Journal of Soil Biology, 2014. 65: pp. 15-22. https://doi.org/10.1016/j.ejsobi.2014.08.007

[33] Abbas, Z., M. Akmal, and K. S. Khan, Effect of buctril super (Bromoxynil) herbicide on soil microbial biomass and bacterial population. Brazilian Archives of Biology and Technology, 2014. 57(1): pp. $9-14$ https://doi.org/10.1590/S1516-89132014000100002

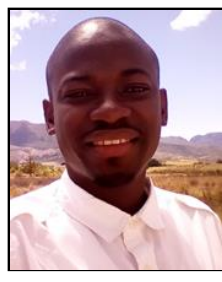

A.T. Adetunji obtained his MTech in Agriculture (Crop management) and $\mathrm{PhD}$ in Environmental Health (Soil Science) at the Cape Peninsula University of Technology (CPUT), Cape Town, South Africa in 2015 and 2020, respectively. Currently, he is a Postdoctoral Fellow in the Department of Agriculture, Cape Peninsula University of Technology, with a focus on examining the impact of different soil management practices on soil biology and quality. 